\title{
A study on awareness about eye health care and eye donation among secondary level students of North Kolkata, India
}

\author{
Biswas J, ${ }^{1}$ Bandyopadhyay S, ${ }^{2}$ Das D, ${ }^{3}$ Mondal KK, ${ }^{4}$ Saha I, ${ }^{5}$ Ray $\mathrm{B}^{6}$
}

\author{
${ }^{1-6}$ Department of Ophthalmology, \\ R.G.Kar Medical College, Kolkata, India
}

\section{Corresponding author}

Dr Jaya Biswas

Department of Ophthalmology,

R.GKar Medical College, Kolkata, India

jayabiswas2008@rediffmail.com

Kathmandu Univ Med J 2010;8(31):317-20

\author{
ABSTRACT \\ Background
}

Corneal blindness is one of the important types of blindness that can be prevented by proper health care education and conventionally cured by corneal transplantation for which awareness regarding eye donation is essential.

\section{Objectives}

The aim of the study is to assess the awareness of eye health care and eye donation among secondary level school students of North Kolkata.

\section{Methods}

It was a cross-sectional study. Settings: Eight Government aided schools of North Kolkata, West Bengal, India. A total of 1525 students of standard VIII, IX and X of Government aided schools of North Kolkata participated in this study. A pre-tested, semi-structured questionnaire was administered on eye health care and eye donation.

\section{Results}

1284 (84.2\%) participants opined that awareness on eye health care can prevent most of the blindness and 1206 (79.1\%) students knew that Vitamin A has important role in prevention of childhood blindness. Majority, 1235 (81.0\%) students were aware of eye donation after death while only 489 (32.1\%) participants knew that the ideal time for eye donation is within 6 hours of death. 802 (52.6\%) participants mentioned printed and electronic media (like newspaper and television) as the major source of information on eye donation.

\section{Conclusions}

Media publicity to increase awareness of eye donation and eye health care is not enough. Strategies have to be developed to educate the students, so that they can act as motivators for enhancing eye donation and increasing eye health care awareness in the community.

Key Words

awareness, corneal blindness, eye donation, school students

\section{INTRODUCTION}

Corneal diseases are important causes of blindness in developing countries like India. ${ }^{1,2}$ Corneal scarring due to keratitis and ocular trauma are major causes of unilateral and bilateral corneal blindness in children and young adults. ${ }^{3}$ The Andhra Pradesh Eye Disease Study (APEDS) conducted between 1996 and 2000 among the rural population of Andhra Pradesh reported the prevalence of corneal blindness at $0.13 \%$ (95\% CI: $0.06-0.24$ ), constituting $9 \%$ of all blindness. ${ }^{4}$ There are approximately 18.7 million cases of blindness in India. ${ }^{5}$ Among them
$1,90,000$ are blind due to bilateral corneal disease. ${ }^{6}$ Each year about 20000 new cases of corneal blindness is added to the existing list. ${ }^{7}$ Though strategies towards prevention of corneal blindness are more cost effective, the major treatment option is corneal transplantation for those who are having corneal blindness. As the current rate of procurement of donor cornea is only about 22,000 per year, the backlog of corneal transplantation is growing. ${ }^{8}$

Students are an important part of our society. Children below the age of 16 years accounts for $40 \%$ of Indian population. ${ }^{9}$ If they are educated about different aspects of 
eye health care and eye donation, they can act as important present and future motivators. ${ }^{10}$ This study was conducted to assess the awareness regarding eye health care and eye donation among secondary level school students of North Kolkata, West Bengal, India.

\section{METHODS}

It was a cross- sectional study and conducted between $25^{\text {th }}$ August to 8 th September 2008, the period that is observed as National Fortnight on Eye Donation in India. The study was carried out in eight randomly selected Government aided schools of North Kolkata. All the students of standard VIII, IX and X of these 8 schools constituted the study population. After having Institutional Ethical Clearance, all the 8 schools were contacted 2 weeks prior to the study. After explaining the nature and purpose of the

Table 1. Responses of the study subjects on different aspects of eye health care

\begin{tabular}{|c|c|c|}
\hline Responses & Number & $\%$ \\
\hline \multicolumn{3}{|l|}{$\begin{array}{l}\text { Most of the blindness can be prevented if awareness are } \\
\text { generated on eye health }\end{array}$} \\
\hline Yes & 1284 & 84.2 \\
\hline No & 150 & 9.8 \\
\hline No response & 91 & 6.0 \\
\hline \multicolumn{3}{|l|}{$\begin{array}{l}\text { Vitamin A has important role in prevention of } \\
\text { childhood blindness }\end{array}$} \\
\hline Yes & 1206 & 79.1 \\
\hline No & 196 & 12.9 \\
\hline No response & 123 & 8.0 \\
\hline \multicolumn{3}{|l|}{$\begin{array}{l}\text { Most of the green leafy vegetables and yellow fruits } \\
\text { contain abundant Vitamin A }\end{array}$} \\
\hline Yes & 1049 & 68.8 \\
\hline No & 338 & 22.2 \\
\hline No response & 138 & 9.0 \\
\hline \multicolumn{3}{|l|}{$\begin{array}{l}\text { Students should take active role in spreading awareness } \\
\text { among family members }\end{array}$} \\
\hline Yes & 1432 & 93.9 \\
\hline No & 25 & 1.6 \\
\hline No response & 68 & 4.5 \\
\hline \multicolumn{3}{|l|}{ First eye screening should be done } \\
\hline Within 6 months of age & 97 & 6.4 \\
\hline 6 months -3 years of age & 821 & 53.8 \\
\hline $3-6$ years of age & 328 & 21.5 \\
\hline No response & 279 & 18.3 \\
\hline
\end{tabular}

study to the school authority, the respective classes of all the schools were briefed to ensure maximum attendance and participation on that particular day of survey. All the schools were surveyed on separate days. Finally, we could cover all the students present on that particular day of survey and that came to 1525 . We used a pre- tested, semistructured questionnaire to obtain information from the students. Questions were in local language and it included demographic details, student's knowledge and awareness regarding eye health care, eye donation and sources of information regarding eye donation. The ophthalmologists and para medical ophthalmic assistants of a tertiary care level hospital of Kolkata collected all the information.

Table 2. Responses of the study subjects on different aspects of eye donation $n=1525$

\begin{tabular}{l|c|c}
\hline \multicolumn{1}{c|}{ Responses } & Number & $\%$ \\
Eyes can be collected from donor after death & & \\
Yes & 1235 & 81.0 \\
No & 95 & 6.2 \\
No response & 195 & 12.8
\end{tabular}

Eye can be donated after death

Within 6 hours

$489 \quad 32.1$

More than 6 hours

No response

Source of information on eye donation

Medical personnel

$201 \quad 13.2$

Teacher

TV, newspaper or other media

Family member

No response

Blind religious belief is an important obstacle in eye

donation

Yes

$1193 \quad 78.2$

No

$239 \quad 15.7$

No response 


\section{RESULTS}

Among 1525 students 687 (45\%) were male and rest 838 (55\%) were female. Out of them 53.9\% respondents belonged to age group $13-15$ years, while $42.2 \%$ and $3.9 \%$ were in the age group $15-17$ and $17-19$ years respectively, with an overall mean age being $14.5 \pm 1.1$ years.

Majority of the respondents (84.2\%) opined that blindness can be prevented if awareness is generated upon eye health care. A large number of respondents (79.1\%) knew that Vitamin A has important role in prevention of childhood blindness and $68.8 \%$ had the knowledge that it is present abundantly in green leafy vegetables and yellow fruits. Almost all the respondents (93.9\%) were in favour of active involvement of themselves in spreading awareness regarding eye donation \& eye health care among their family members. Only 97 respondents $(6.4 \%)$ were in favour of first eye screening within 6 months of age (Table 1).

Among 1525 respondents 1235 (81.0\%) students were aware about eye donation but only $32.1 \%$ (489) knew that ideally it should be collected within 6 hours of death. Mass media like TV, newspaper and others was the major source of information on eye donation according to 802 (52.6\%) students. Blind religious belief was mentioned as an important obstacle in eye donation by $78.2 \%$ respondents (Table 2).

\section{DISCUSSION}

A large proportion of corneal blindness is avoidable. ${ }^{11}$ Though strategies to prevent corneal blindness are more cost effective, corneal transplantation remains the major treatment option. The statistics on eye donation in India shows that there is a considerable and constantly growing backlog of corneal transplantation8. In the present scenario it is essential to enhance the awareness regarding eye donation among the potential donors in an effort to increase the procurement of corneas.

In the present study $81 \%$, students had knowledge of eye donation. In a study conducted among medical students 99.4\% participants were aware of eye donation. ${ }^{1}$ In another study among south Indian population, $50.7 \%$ respondents were aware of it. ${ }^{14}$ Only $32.1 \%$ students knew that the ideal time for eye donation is within 6 hours of death. A study on medical students observed that $41.1 \%$ of them knew the ideal time for eye donation 1 . Another study conducted on medical and non- medical students revealed that $63.3 \%$ of the former group and $62.5 \%$ of the non- medical students were aware of eye donation within 6 hours of death. ${ }^{10}$ The timing of eye donation is very important. If the eyes can not be collected within 6 hours of death, they may not be utilized for optical purpose. Thus, lack of knowledge regarding optimal timing for eye donation will lead to underutilization of donated corneas.

Present study revealed that large number of students (79.1\%) had knowledge about vitamin A's important role in prevention of childhood blindness and $68.8 \%$ had knowledge about the dietary sources of vitamin A. They have acquired this knowledge as they are being taught about it in their classes.

Using mass media to increase the awareness regarding corneal blindness and eye health care to avoid it and at the same time eye donation to treat corneal blindness is not enough. There is a great need to educate students, as they are an important part of our society. If they are educated about the preventive and curative aspects of corneal blindness, they can spread the message among their friends and family members, thus acting as important motivators. It is also essential to dispel their misconception regarding eye donation.

Although grief counselling of relatives by hospital medical staff has been successful in procuring organs in case of death in hospitals, the consent of family members is important in procuring corneas. ${ }^{12,13}$ If the students are educated they can raise the awareness among their family members thus ultimately enhancing eye donation rates.

\section{CONCLUSIONS}

Students are the future of every society, as well as potential messenger to transmit different information. Although most of the students are in favour of active involvement to transmit knowledge, but lack of awareness is the main hindrance. Data from our study suggests that only media publicity is not enough to increase the awareness regarding eye health care and eye donation. Therefore, inclusion of different preventive and curative aspects of corneal blindness along with basic eye health care into the course curriculum is the need of the hour.

\section{ACKNOWLEDGEMENT}

We would like to offer our heartiest thanks to Students' Health Home, Kolkata and Head of the Institutions of all eight schools to help us in carrying out the study. We are also grateful to all the teaching staffs, students of those schools and para medical ophthalmic assistants of RG Kar Medical College who helped us in data collection and for their participation in this study. 


\section{REFERENCES}

1. Singh MM, Rahi M, Pagare D, Ingle GK. Medical students' perception on eye donation in Delhi. Indian J Ophthalmol 2007;55:49-53.

2. Krishnaiah S, Kovai V, Nutheti R, Shamanna BR, Thomas R, Rao GN. Awareness of eye donation in the rural population of India. Indian J Ophthalmol 2004;52:73-8.

3. Whitcher JP, Srinivasan M, Upadhyay MP. Corneal blindness: a global perspective. Bull World Health Organ 2001;79:214-21.

4. Dandona L, Dandona R, Srinivas M, Giridhar P, Vilas $\mathrm{K}$, Prasad MN, et al. Blindness in Indian state of Andhra Pradesh. Invest Ophthalmol Vis Sci 2001;42:908-16.

5. Dandona L, Dandona R, John RK. Estimation of blindness in India from 2000 through 2020: Implications for the blindness control policy. Natl Med J India 2001;14:327-34.

6. India. National Program for the Control of Blindness. Report of National Program for the Control of Blindness, India and World Health Organisation. [Publisher Unknown] 1986-89.

7. Saini JS, Reddy MK, Jain AK, Ravindra MS, Jhaveria S, Raghuram L. Perspective in eye banking. Indian J Ophthalmol $1996 ; 44: 47-55$.
8. Gupta A, Jain S, Jain T, Gupta K. Awareness and Perception Regarding Eye Donation in Students of a Nursing College in Bangalore. Indian Journal of Community Med 2009;34:122-5.

9. Office of the Registrar General and Census Commissioner, India. Population projects for India and States 2001- 2026 (Revised December 2006). New Delhi: Registrar General and Census Commission, Govt. of India; 2006.

10. Dhaliwal U. Enhancing eye donation rates. Training students to be motivators. Indian J Ophthalmol 2002;50:209-12.

11. Mohan M. Survey of Blindness-India (1986-1989): Summary Results. New Delhi: Programme for the Control of Blindness, Ministry of Health and Family Welfare, Government of India; 1992.

12. Stark JL, Reiley P, Osiecki A, Cook L. Attitudes affecting organ donation in the intensive care unit. Heart Lung 1984; $13: 400-4$.

13. Vernale C. Critical care nurses' interactions with families of potential organ donors. Focus Crit Care 1991;18:335-9.

14. Priyadarshini B, Srinivasan M, Padmavathi A, Selvam S, Saradha A, Nirmalan PK. Awareness of eye donation in an adult population of southern India. A pilot study. Indian J Ophthalmol 2003;51:101-4. 